\title{
TARSYIH KEPEMIMPINAN DALAM PERSPEKTIF TAFSIR DAN UNDANG-UNDANG PEMILU NOMOR 7 TAHUN 2017
}

\author{
Nadirsah Hawari, Rachma Octariani, Eva Rosalia \\ Sinta Arifka. A, Asep Candra \\ Fakultas Ushuluddin dan Studi Agama UIN Raden Intan Lampung \\ nadirsahhawari@radenintan.ac.id
}

Diterima: 02 Maret 2019 Disetujui: 15 Juni 2019 Dipublikasikan: 25 Juni 2019

\begin{abstract}
According to Islamic Shari'a, holding a public office is not a right for an individual, but an obligation for the State. Therefore, the government, both the regional head and all its officials, must select the most suitable and most suitable person for every government job. It should not be made of nepotism by looking at kinship, friendship, or faction from any relationship with the eligibility of someone to hold a position. The existing rulers should appoint officials from the best people (al-ashlah), the Prophet said which means "whoever holds a Muslim's business (meaning being a ruler) then he appoints someone to be an official even though he knows there are more people good for (benefit) of the Muslims, then really he has betrayed Allah and His Messenger "(Ibn Taimiyah). If the head of state or other officials do not find the right person for a certain position, in this situation they must choose the person who is more representative. Representative here means the person who is the most appropriate from the one for each government position. And also in this selection process, the head of state and other officials must know about the standards of eligibility al-quwwah (strength) and al-amanah (trust). Al-Quwwah is the ability and feasibility of a job assignment. Whereas trusteeship is a behavior that focuses on the management process regarding the position or function of a position that is in accordance with Islamic Shari'a with the intention of only devoting to Allah and not based on fear of humans and expecting their self-interest. nominating yourself is
\end{abstract}




\title{
Nadirsah Hawari, Rahma, Sinta, Asep:TARSYIH KEPEMIMPINAN .....
}

required to convey the vision and mission and the state program that will be implemented. In this case, the community or community is very necessary to obtain information on the candidate pairs who nominate themselves, and the campaign that can be used as a means of communicating politics and public education. The leaders, servants of the State, civil servants or the military, judges and so on, are essentially representations of the voices of the people they lead. The leaders are no more than public servants who must devote and dedicate their leadership to the benefit of the people. The leaders are only representatives of the fulfillment of the rights of the people, so that they are obliged to run the government properly.

\section{Keywords: Leadership, Leaders, Islamic Shari'a}

\begin{abstract}
Abstrak
Menurut syariat islam, memegang suatu jabatan-jabatan umum bukanlah hak bagi individu, melainkan kewajiban atasnya bagi Negara. Oleh sebab itu, pemerintah baik kepala daerah dan seluruh pejabatnya harus menyeleksi orang yang paling cocok dan paling layak bagi setiap pekerjaan pemerintahan.Tidak boleh beerbuat nepotisme dengan memandang kekerabatan, persahabatan, atau golongan dari manapun yang tidak ada hubunngannya dengan kelayakan seseorang untuk memegang suatu jabatan.Para penguasa yang telah ada hendaknya mengangkat para pejabat dari orang orang terbaik (al-ashlah), Nabi bersabda yang artinya "barang siapa memegang suatu urusan kaum muslimin (maksudnya menjadi penguasa) kemudian ia mengangkat seseorang menjadi pejabat padahal ia mengetahui ada orang yang lebih baik bagi (kemaslahatan) kaum muslimin, maka sungguh ia telah mengkhianati Allah dan Rasul-Nya" (Ibnu Taimiyah). Apabila kepala Negara atau para pejabat lainnya tidak menemukan orang yang tepat untuk suatu
\end{abstract}




\section{Nadirsah Hawari, Rahma, Sinta, Asep:TARSYIH KEPEMIMPINAN .....}

jabatan tertentu, dalam keadaan ini mereka harus memilih orang yang lebih representative. Representative disini memiliki arti yakni orang yang paling tepat dari yang ada untuk setiap jabatan pemerintahan. Dan juga dalam proses penyeleksian ini, kepala Negara dan pejabat lainnya harus mengetahui tentang standar kelayakan al-quwwah (kekuatan) dan al-amanah (kepercayaan).Al-Quwwah ialah kemampuan dan kelayakan suatu tugas jabatan. Sedangkan amanah, merupakan perilaku yang dititik beratkan pada proses pengelolaan perihal jabatan atau fungsi dari suatu jabatan yang sesuai dengan syariat islam dengan niat hanya bertaqwa kepada Allah dan bukan berdasar pada ketakutan kepada manusia dan mengharap pamrih dari mereka.Didalam pelaksanaan kampanye, pasangan calon kandidat yang mencalonkan diri diharuskan untuk menyampaikan visi dan misi serta program kenegaraan yang akan dijalankan. Dalam hal ini, umat atau khalayak masyarakat sangat perlu untuk memperoleh informasi atas pasangan calon kandidat yang mencalonkan diri tersebut, dan kampanyelah yang dapat dijadikan sebagai sarana berkomunikasi politik dan pendidikan masyarakat. Para pemimpin, abdi Negara, pegawai sipil atau militer, hakim dan lain sebagainya, pada hakikatnya merupakan representasi suara rakyat yang mereka pimpin. Para pemimpin tidaklah lebih dari pelayan masyarakat yang harus mengabdikan dan mendedikasikan kepemimpinannya untuk kemaslahatan rakyat. Para pemimpin hanyalah wakil akan pemenuh hak hak umat, sehingga mereka wajib menjalankan roda pemerintahan dengan baik.

\section{Kata kunci : Kepemimpinan, Pemimpin, Syariat Islam}

\section{Pendahuluan}

Kata kunci penting dalam definisi kepemimpinan adalah pemimpin. Pemimpin adalah tokoh atau anggota masyarakat yang dikenal secara langsung atau tidak langsung oleh para pengikutnya. Pemimpin dapat dikelompokan menjadi pemimpin formal dan 


\section{Nadirsah Hawari, Rahma, Sinta, Asep:TARSYIH KEPEMIMPINAN .....}

pemimpin informal. Pemimpin formal adalah pemimpin yang menduduki posisi atau jabatan formal kepemimpinan dalam suatu organisasi formal yang didirikan berdasarkan undang-undang atau peraturan negara. Sedangkan pemimpin informal adalah pemimpin yang tidak menduduki jabatan organisasi formal dalam sistem sosial akan tetapi mempunyai pengaruh terhadap para anggota sistem sosoal. Kesuksesan kepemimpinan ditentukan oleh banyaknya faktor seperti para pengikut, situasi lingkungan internal dan eksternal sistem sosial dan sumber-sumber kepemimpinan yang tersedia. ${ }^{1}$

Pemimpin nti dari kepemimpinan adalah pemimpin yang setiap organisasi atau sistem sosial mempunyai sebutan atau predikat yang berbeda. Dalam kepemimpinan politik pemimpin disebut sebagai presiden raja atau perdana mentri, ketua DPR, ketua partai dan sebagainya.

Kepemimpinan yang dalam bahasa inggrisnya adalah "leadership", merupakan aspek terpenting bagi seorang pemimpin negara, karena seorang pemimpin harus berperan sebagai penggerak kelompok untuk mencapai tujuan yang telah ditetapkan dalam sistem peraturan negara. Kepemimpinan dapat di definisikan sebagai susastu proses untuk mengerahkan dan mempengaruhi aktivitas yang berhubungan dengan penguasa anggota organisasi dalam rangka mencapai tujuan kelompok organisasi.

Kepemimpinan menurut Cribbin adalah kemampuan memperoleh konsensus dan keikatan pada sasaran bersama, melampaui syaratsyarat organisasi, yang dicapai dengan pengalaman sumbangan dan kepuasan di pihak kelompok kerja. ${ }^{2}$

istilah yang umum dapat dartikan sebagai suatu kegiatan mempengaruhi orang-orang agar bekerjasama untuk mencapai suatu tujuan yang mereka inginkan. Kepemimpinan adalah mempengaruhi

${ }^{1}$ DR. Wirawan Wirawan, MSI, SP.A.,M.SI, "KEPEMIMPINAN," cetakan ke 1, juni 2013) Hal 9.

${ }^{2}$ James J. Cribbin, Kepemimpinan Strategi Mengefektifkan Organisasi, (Jakarta: PT Gramedia, 1990), h. 12 


\section{Nadirsah Hawari, Rahma, Sinta, Asep:TARSYIH KEPEMIMPINAN .....}

tingkah laku manusia dan kemampuan-kemampuan untuk membimbing orang. ${ }^{3}$

\section{Metode}

Penelitian ini sifatnya kualitatif dan jenis penelitian ini adalah library research. Alat pengumpulan data menggunakan dokumentasi yang berbentuk naskah, dokumen dan literatur buku. Sumber data pada penelitian ini ada dua yaitu sumber primer dan sumber sekunder. Cara analisis data menggunakan mengolah data yang ada lalu dijabarkan dan diambil kesimpulan.

\section{Hasil dan Pembahasan \\ Bekal Seorang Pemimpin}

Untuk memjadi seorang pemimpin, seseorang harus memiliki bekal yang cukup. Bekal itu berupa kekuatan yang akan digunakan untuk menggerakkan semua orang yang dipimpin nya. Kekuatan itu merupakan buah pikiran atau ide, pendapat, wawasan, kemampuan melihat masa depan untuk menentukan kemana arah lembaga yang dipimpin akan dikembangkan, potensi yang ada, cara-cara yang akan ditempuh untuk meajukan lembaga yang akan dipimpin, dan bahkan bagaimana mengatasi rintangan yang mungkin timbul dalam berbagai bentuk.

Atas dasar kekuatan itu, maka pemimpin akan mendapatkan pengakuan dan diikuti bawahannya. Pengakuan loyalitas dan keikutsertaan bawahannya akan diberikan secara tulus manakala pemimpin mampu menunjukan kelebihannya. Selain itu juga, sebagai pemimpin yang memilki bekal yang cukup tidak akan melarang mereka yang dipimpinnya melakukan inovasi, pembaruan, dan kreasikreasi baru. Ciri khas pembaru selalu berani berfikir diluar kebiasaan. Pemmpin masa depan atau pemimpin yang sukses di zaman demokrasi seperti sekarang ini adalah mereka yang selalu mengajak

\footnotetext{
${ }^{3}$ Triono, "Jurnal TAPIs," Jurnal TAPIs, (Vol. 9/No. 5 Januari-Juni 2009), 2009, H.79-80.
} 


\section{Nadirsah Hawari, Rahma, Sinta, Asep:TARSYIH KEPEMIMPINAN .....}

anak buahnya berfikir out of the box, dan bukan menyuruh berfikir dan melakukan sesuatu yang hanya sesuai dengan petunjuk $\operatorname{arahannya}^{4}$

Ibnu Umar berkata bahwa Rasulullah bersabda:

"Setiap kamu adalah pemimpin dan setiap kamu bertanggung jawab terhadap kepemimpinan bagi rakyatnya dan bertanggung jawab tentang mereka. Seorang wanita adalah pemimpin bagi rumah suaminya dan bertanggung jawab atasnya. Pun seorang budak adalah pemimpin atas harta dan bertanggung jawab atasnya" 5

Islam sendiri memandang kepemimpinan merupakan sebuah hal yang terpenting dalam menjalankan suatu roda pemerintahan negara, organisasi, institusi, dan sebagainya. Pemimpin negara dalam perspektif islam merupakan wakil umat, atau lebih tepatnya pegawai umat. Diantara hak yang mendasar, wakil layak diperhitungkan atau perwakilan itu layak dicabut jika memang dikehendaki,terutama jika orang yang mewakili mengabaikan berbagai kewajiban yang harus dilakukannya.

Pimpinan dalam suatu jama'ah, ibarat kepala bagi tubuh. Inilah yang menentukan seluruh tujuan, dan disini pula tempat berkumpulnya segala macam informasi. Pemimpin bertugas memikirkan dan mengkaji setiap masalah yang dihadapi. Dalam pelaksanaannya, dapat saja dibantu oleh para anggota yang berkemampuan, atau tim khusus. Pimpinan memberikan arahanarahan dan harus mengawasi dan menhendalikan pelaksanaannya. Dengan demikian gerakan dapat berjalan berksinambungan dan selalu pada garis yang benar.

Kepemimpinan negara yang sukses adalah pemimpin yang mampu mempengaruhi prilaku individu-individu, untuk menunaikan tugasnya memberikan arahan dan petunjuk, mewujudkan target

${ }^{4}$ Suprayogo, Imam Masyarakat Tanpa Ranking (Membangun Bangsa Bersendi Agama) (Jakarta: PT Elex Media Komputindo,2013, 2013), H.3-5.

${ }^{5}$ H.R. Bukhari, No. 853. 


\section{Nadirsah Hawari, Rahma, Sinta, Asep:TARSYIH KEPEMIMPINAN .....}

jama'ah, mengembangkan, memegang teguh, dan menjaga kekuatan bangunannya $^{6}$

Islam sendiri sebagaimana tercantum dalam Al-qur'an mengandung berbagai nilai, aturan, dan konsep yang berkaitan dengan sistem akidah, syariah, ahlak dan sebagainya yang diperlukan manusia dalam hidupnya. Kepemimpinan dalam islam, bahkan sepanjang sejarah peradaban islam selalu berkaitan dengan istilah konsep yang digunakan, macam dan hirarkinya. Perbincangan kepemimpinan dalam islam tidak jauh berbeda dengan pembicaraan tentang akidah, ibadah, dan sendi-sendi ajaran islam lainnya.

Hal itu penting karena adanya seorang pemimpin adalah suatu kewajiban. Dalam islam sendiri kata kepemimpinan disebut dengan kata "imamah" dan " khalifah". Kata " imamah" lazim dipakai oleh kaum syi'ah dan kata "khalifah" dipakai olhbkaum ahlu sunnah. Kedua konsep tersebut mengandung makna kepemimpinan dan keuasaan. Walaupun demikian kedua konsep kedua konsep yang menjadi ciri khas masing-masing antara sunni dan syi'ah mengandung prinsip=prinsip yang berbeda.

Jumhur ulama memberikan pengrtian tentang kepemimpinan, dengan menggunakan kata imamah dan khalifah diantaranya sebagai berikut: imamah adalah kedudukan (lembaga) yang dibentuk untuk menggantikan fungsi kenabian dalam memelihara agama dan mengatur urusan dunia. Sedangkan ibrahim hasan dalam bukunya mendefinisikan, bahwa khilafah adalah bentuk kekuasaan umum dalam urusan agama dan dunia sebagai pengganti nabi.

Berdasarkan pada beberapa pengertian diatas, maka dapat dismpulkan bahwa pemimpin adalah orang yang terlibat dalam proses kepemimpinan, kepemimpinan negara adalah sebuah sistem, seorang pemimpin harus mampu menjadi fasilitator, bagi bawahannya dalam hal tugas atau pekerjaan yaitu dengan memberikan jalan keluar, pendapat atau informasi terhadap masalah yang dihadapi kelompoknya, serta mengendalikan kelompoknya untuk mencapai

${ }^{6}$ Triono, "Jurnal TAPIs," H. 70-71. 


\section{Nadirsah Hawari, Rahma, Sinta, Asep:TARSYIH KEPEMIMPINAN .....}

tujuan dengan memotivasi dan menjadi tauladan pribadi yang baik kepada bawahannya dan menciptakan suasana kerja yang harmonis dalam rangka kemaslahatan dunia akherat ${ }^{7}$

\section{Syarat-Syarat Kepemimpinan}

Kartono mengatakan bahwa persyaratan kepemimpinan itu harus selalu dikaitkan dengan tiga hal penting, yaitu :

1. Kekuasaan, Yaitu otoritas dan legalitas yang memberikan kewenangan kepada pimpinan guna mempengaruhi dan menggerakkan bawahan untuk berbuat sesuatu.

2. Kelebihan, keunggulan, keutamaan sehingga orang mampu mengatur orang lain, sehingga orang tersebut patuh pada pemimpin, dan bersedia melakukan perbuatan-perbuatan tertentu.

3. Kemampuan, yaitu segala daya, kesanggupan, kekuatan dan kecakapan/keterampilan teknis maupun social yang di anggap melebihi dari kemampuan anggota biasa

Stogdill mengatakan bahwa pemimpin harus memiliki beberapa kelebihan, yaitu:

a) Kapasitas, yaitu kecerdasan, kewaspadaan, kemampuan berbicara atau verbal facility, keaslian, dan kemampuan menilai.

b) Prestasi atau achievement, yaitu gelar kesarjanaan, ilmu pengetahuan perolehan dalam olahraga dan atletik, dll

c) Tanggung jawab, yaitu mandiri, berinisiatif, tekun, ulet, percaya diri, agresif, dan punya hasrat untuk unggul

1. Partisipasi, yaitu aktif, memiliki sosiabilitas tinggi, mampu bergaul, kooperatif atau suka bekerja sama, mudah menyesuaikan diri, punya rasa humor.

2. Status, yaitu memiliki kedudukan social ekonomi yang cukup tinggi, populer dan tenar dan jika syarat-syarat untuk menjadi pemimpin terpenuhi, maka akan melahirkan pemimpin yang berkualitas ${ }^{8}$.

\footnotetext{
${ }^{7}$ Triono, H.80-81.

${ }^{8}$ Pasolong Harbani, Kepemimpinan Birokrasi (Bandung: Alvabeta, 2010),
} H.11-12. 


\section{Nadirsah Hawari, Rahma, Sinta, Asep:TARSYIH KEPEMIMPINAN .....}

\section{CIRI CIRI PEMIMPIN YANG BAIK}

Maxwell mengatakan bahwa untuk menjadi pemimpin yang baik harus memiliki cirri-ciri:

1. Pemimpin yang baik mampu menciptakan lingkungan yang tepat, cara paling baik untuk memiliki loyalitas personel ialah dengan memperlihatkan perhatian kepada mereka dengan kata-kata dan perbuatan.

2. Pemimpin yang baik mengetahui kebutuhan besar bawahannya.

3. Pemimpin yang baik mampu mengendalikan keuangan, personalia, dan perencanaan.

4. Pemimpin yang bai mampu menghindari tujuh dosa besar yang mematikan :

5. Berusaha untuk disukai bukan dihormati

6. Tidak meminta nasihat dan bantuan orang lain

7. Mengesampingkan bakat pribadi dengan menekan peraturan bukan keahlian

8. Tidak menjaga untuk dikritik tetap konstruktif

9. Tidak mengembangkan rasa tanggung jawab dalam diri orang lain

10. Memperlakukan orang dengan cara yang sama

11. Tidak membuat orang selalu mendapat informasi

Hasil penelitian Kousez dan Ponser pada tahun 1987, tahun 1995, dan tahun 2002 yang dilakukan pada enam benua yaitu Afrika, Amerika Selatan, Asia, Eropa, dan Amerika Serikat, menunjukkan bahwa cirri khas kepemimpinan yang paling dikagumi yaitu:

1. Jujur

2. Berorientasi ke depan

3. Kompeten

4. Membangkitkan semangat

5. Cerdas

6. Berwawasan adil

7. Berwawasan luas 


\title{
Nadirsah Hawari, Rahma, Sinta, Asep:TARSYIH \\ KEPEMIMPINAN .....
}

\author{
8. Mendukung \\ 9. Dapat dipercaya \\ 10. Dapat diandalkan \\ 11. Kooperatif \\ 12. Tegas \\ 13. Imajinatif \\ 14. Ambisius \\ 15. Berani \\ 16. Perhatian \\ 17. Dewasa \\ 18. Setia \\ 19. Pengendalian diri \\ 20. Independen
}

Riset Kousez dan Posner dilakukan terhadap ribuan eksekutif swasta dan pemerintah (pemimpin birokrasi). Riset tersebut menunjukkan bahwa para pengikut mengharapkan pemimpin yang mempunyai karakteristik seperti kejujuran, berorientasi ke depan, kompeten, dan membangkitkan semangat pengikut.

Jadi, pendekatan yang digunakan oleh Kousez dan Posner adalah pendekatan sifat-sifat kepemimpinan.Kelemahan pendekatan ini sampai saat ini belum satupun penelitian yang menggunakan pendekatan ini berhasil secara memuaskan. Karena selalu saja terjadi sifat-sifat kepemimpinan yang ditemukan tumpang tindih bahkan kontradiktif $^{9}$

\section{Konsep kepemimpinan dalam islam}

Kepemimpinan merupakan sebuah sistem organisasi kemasrakatan atau kelembagaan, maka secara ideologis/filosofis mengenai sifat dan sumber dari kepemimpinan dapat dasarkan pada nilai-nilai agama dan adat istiadat yang berlaku dalam suatu masyarakat. Konsep kepemimpinan dalam islam yang didasarkan kepada wahyu sebagai setandar nilai bagi kepemimpinan, setidak-

${ }^{9}$ Ibid .H.12-14. 


\section{Nadirsah Hawari, Rahma, Sinta, Asep:TARSYIH KEPEMIMPINAN .....}

tidaknya merupakan karakter yang melekat pada diri pemimpin, adalah sebagai berikut:

1. Menegakkan kebenaran

2. Beriman kepada ALLAH SWT

3. Meneladani Rosul Saw

4. Sifat-sifat pemimpin menrut wahyu ilahi:amanah, fatonah, shiddiq, tabligh

Dari paparan diatas, dapat disampaikan bahwa kepemimpinan masyarakat atau sebuah institusi, dimanapun, kapanpun dan dalam keadaan apapun harus selau dapat menentramkan masyarakat yang dipimpinnya, dengan membrikan keteladanan yang baik untuk ditiru, dan dijadikan rujukan bagi kehidupan para pengikutnya. Dengan demikian seorang pemimpin pada hakikatnya adalah keteladanan ${ }^{10}$

\section{A. BEREBUT KEKUASAAN}

Pemilihan kepala desa, bupati dan wali kota,gubernur, presiden dan wakil presiden, anggota lagislatif, mulai dari tingkat kabupaten kota, provinsi dan pusat, menjadikan suasana mengejar kekuasaan sangat kelihatan. Demi memperebutkan hal tersebut, calon penguasa diiklankan baik melalui media masa hingga memasang gambargambar atau foto-foto yang bersangkutan di tempat-tempat strategis. Semua dimaksudkan untuk mempekenalkan diri dan wilayah ke masyarakat calon pemilih.

Suasana yang terjadi adalah berebut popularitas bagaikan sebuah komoditas, maka calon pemimpin harus diiklankan, cara mengiklankannya seperti memeberikan penjelasan tentang kelebihan dan prestasi pemimpin tersebut dalam bentuk pertemuan-pertemuan. Pada zaman dahulu, sekalipun jabatan itu diinginkan, orang merasa

10“Komunikasi Politik," Cangara,Hafied.2009. Komunikasi Politik. jakarta:PT Graphindo Persada, 2009. 


\section{Nadirsah Hawari, Rahma, Sinta, Asep:TARSYIH KEPEMIMPINAN .....}

malu mengajukan dirinya sendiri agar dipilih sebagai pemimpin. Biasanya orang lain yang mengajukannya.

Pada saat sekarang ini rupanya keadaannya sudah jauh berubah, seseorang yang tidak pernah memberi sesuatu kepada masyarakatpun berani mencalonkan diri sebagai pemimpin. Itulah sebabnya diperlukan pengenalan diri bahkan lewat iklan dengan berbagai cara. Tidak sekedar itu, untuk memengaruhi masyarakat agar memilihnya juga tidak jarang menggunakan cara-cara yang tidak semestinya.Misalnya, dengan menggunakan politik uang.

Keaadan seperti itulah sebenarnya yang menjadikan sumber korupsi dimana-mana. Tidak sedikit oknum pejabat politik seperti bupati,gubernur,walikota, anggota legislatif menjadi tersangka korupsi dan akhirnya dimasukkan kepenjara. Jabatan dalam suasana seperti ini tidak ubahnya usaha bisnis mereka mengeluarkan modal untuk mendapatkan keuntungan dikemudian hari.

Islam memandang bahwa jabatan atau kekuasaan adalah amanah yang harus ditunaikan sebaik baiknya.Sebaagai amanah, maka tidak selayaknya jabatan diperebutkan apalagi kemudian dijadikan sebagi komoditas untuk mencapai keuntungan pribadi. Namun jika amanah itu diberikan, maka ia tidak boleh ditolak danharus ditunaikan dengan sebaik-baiknya. Akhir-ahir ini, terkait dengan politik banyak orang merasa kecewa dan jengkel karena cenderung menjadi sumber korupsi dimana-mana dan diantara penyebabnya adalah karena kekuasaan selalu diburu dan dipandang sebagai komoditas untuk mendapatkan keuntungan ${ }^{11}$.

Perebutan kursi "jabatan" sebagai anggota DPR dan DPRD di negri ini terbilang banyak peminatnya, dari masyarakat golongan atas hingga golongan bawah, baik berpendidikan tinggi hingga yang berpendidikan menengah kebawah.Bannyaknya keinginan masyarakat untuk menduduki kursi "jabatan" dinegri ini patut diapresiasi, dari sini bisa dilhat banyak putra-putri negri ini yang ingin berpartisipasi

\footnotetext{
${ }^{11}$ Imam Masyarakat Tanpa Ranking (Membangun Bangsa Bersendi Agama), H.39-41.
} 


\section{Nadirsah Hawari, Rahma, Sinta, Asep:TARSYIH KEPEMIMPINAN .....}

memajukan dan mensejahterakan gerakan negri terutama didaerahnya masing-masing.

Atas nama rakyat!, adalah kalimat yang sering diucapkanuntuk memikat hati rakyat. Banyak janji-janji calon pemimpin "calon legislatif" diketika berada datas panggung kampanye. Ada calon legislatif "caleg" yang mengambil hati rakyat dengan cara yang sangat tidak mendidik seperti caleg yang melakukan politik uang, halalkan segala cara demi tercapainyaa sebuah kedudukan/jabatan di pemerintahan $^{12}$

\section{Konsep Islam Tentang Pencalonan Diri Dan Kampanye}

Kampanye ialah sebuah tindakan yang bersifat persuasi. Persuasi yang berarti menghimbau atau perilaku mengajak seseorang dengan cara memberikan alas an serta prospek yang baik untuk meyakinkannya.

Pelaksanaan kampanye merupakan salah satu bagiam atas terselenggaranya pemilihan umum. Oleh karena itu dalam hal ini kampanye adalah sebuah sarana sebagai tahap perkenalan diri oleh kandidat yang mencalonkan diri agar khalayak mengetahui keberadaan serta identitas para pihak yang mencalonkan diri tersebut, sehingga dengan demikian umat dapat mengenal dan mampu untuk memilih dan memilah manakah calon kandidat yang pantas untuk menduduki kepemimpinan melalui pemilihan umum.

Adapun pihak-pihak yang melaksanakan kegiatan kampanye ini adalah sekelompok tim kampanye yang dibentuk dari partai politik atau gabungan partai politik tertentu. Partai politik yang dipahami sebagai sebuah organisasi public yang memperjuangkan nilai-nilai islam dalam konteks yang berbeda-beda melalui penguasaan struktur kelembagaan pemerintah baik pada level legislative, maupun eksekutif yang diperoleh dalam pemilihan umum serta melakukan kampanye

\footnotetext{
${ }^{12}$ Putra Andiko, Fenomena Perebutan Kursi “Jabatan” Legislatif sebagai
} objek penciptaan seni lukis (Padang Panjang: Prodi seni murni-fakultas seni rupa dan desain-institut seni indonesia Padang Panjang.), H.2. 


\section{Nadirsah Hawari, Rahma, Sinta, Asep:TARSYIH KEPEMIMPINAN .....}

dengan menjual isu dan program-program yang tidak terlepas dari nilai-nilai ideologis islam.

a. Hak pencalonan (Haqq al-Tarsyih)

Hak pencalonan ialah tindakan seseorang yang mencalonkan dirinya untuk salah satu jabatan pemerintahan atau fungsi umum lainnya. Di sisi lain, tindakan pencalonan diri yang didalamnya mengandung unsure-unsur permintaan akan suatu jabatan tertentu, tentu tidak diperbolehkan secara syariat.

Adapun pencalonan yang memiliki unsure permintaan suatu jabatan oleh individu tidak diperbolehkan, namun boleh hukumnya mencalonkan seseorang untuk orang lain, karena hal tersebut tidak mengandung unsure untuk meminta jabatan (kekuasaan). Akan tetapi mengandung permintaan kepada umat untuk memilih calon yang layak.

b. Kampanye pencalonan

Apabila pada masa kontemporer ini dalam praktiknya pencalonan boleh dilakukan karena dalam keadaan darurat.

Maka bagi orang yang mencalonkan dirinya tidak diperbolehkan untuk melakukan apa yang disebut sebagai kampanye pemilihan yang dilakukan dengan memuji-muji dirinya sendiri dan merendahkan calon-calon yang lain. Namun, seseorang calon boleh memperkenalkan dirinya kepada para pemilih dan menjelaskan gagasan dan langkah-langkah kebijaksanaan kerjanya. Hanya sebatas itu saja yang diperbolehkan oleh calon yang mencalonkan diri ${ }^{13}$.

- Berebut kekuasaan dengan kampanye

${ }^{13}$ Ashubli Muhammad., "perspektif hukum islam terhadap pencalonan diri dan kampanye untukjabatan politik," Jurnal (perspektif hukum islam terhadap pencalonan diri dan kampanye untukjabatan politik) jurusan syariah STAIN bengkalis-riau, H. 14-17. 


\title{
Nadirsah Hawari, Rahma, Sinta, Asep:TARSYIH KEPEMIMPINAN .....
}

\begin{abstract}
Kampanye dipahami sebagai kegiatan yang dilaksanakan oleh organisasi politik atau calon yang bersaing memperebutkan kedudukan diparlemen dsb

Untuk mendapatkan dukungan massa pemilih disuatu pemungutan suara $^{14}$
\end{abstract}

\section{Bukan Sembarang Kursi}

Saat ini banyak orang yang berebut kursi.Bukan sembarang kursi, tetapi kursi yang menarik bagi semua orang. Mereka yang duduk ditempat itu, suaranya didengarkan, printahnya diikuti, keputusannya dijadkan pedoman, berprestasi, dan tentu siapa saja yang duduk dikurssi itu akan mendapatkan sesuatu yang selalu dicari oleh banyak orang. Kursi yang dimaksud itu tidak lain dan tidak bukan adalah kursi kekuasaan.

Dulu dizaman kerajaan, kekuasaan tidak diburu, tetapi cukup ditunggu, berbeda dengan zaman feodal adalah saat orang percaya pada sistem demokrasi seperti ahir-ahir ini.Siapapun bisa menjadi bupati, walikota, gubernur, anggota DPRD, DPR, dan bahkan Presiden.Semua jabatan yang harus diperoleh lewat pemilihan dengan melibatkan rakyat, maka siapa pun berpeluang untuk meaihnya.Siapapun orangnya boleh mencalonkan diri asal mau memenuhi syarat, berani dan merasa mampu.Lewat demokrasi, posisi atau peran seseorang bisa berubah denan cepat.Namun hal yang perlu disadari adalah bahwa apapun tidak terkecuali berdemokrasi yang sedang berjalan saat ini, juga ada risiko. Seseorang yang terlalu bersemangat, prcaya diri tidak memiliki kemampuan konkulasi politik, kemudian ikut mencalonkan diri sebagai pejabat politik dan gagal, maka akan kalah segala-galanya. Risiko juga kadang menimpa mereka yang sukses.Seseorang menjadi pejabat politik melakukan korupsi, ahirnya ditangkap KPK dan kemudian dipenjarakan.Kerugian dialami oleh rakyat, mereka diberi janji-janji indah yang kadang

${ }^{14}$ Efriza, political explore, h.468. 


\section{Nadirsah Hawari, Rahma, Sinta, Asep:TARSYIH KEPEMIMPINAN .....}

berlebihan.Tidak sekedar itu, rakyat juga mendapatkan pelajaran bahwa jabatan ternyata bukan pengabdian, melainkan media untuk mendapatkan keuntungan. Cara berfikir demikian itulah menjadikan demokrasi salah arah, rakyat digiring tidak memilih calon pemimpin kompeten,berpengalaman, mampu memimpin dan menyejahterakan rakyat, melainkan sekedar diajak untuk mengikuti siyapa yang memberikan sesuatu paling menguntungkan. Terjadilan praktik jual beli suara, money politik, suasana seba transaksional,dan efek negatif lainnya. Bebagai bentrok terkait pilkada terjadi di beberapa tempat dan kasus-kasus korupsi sebenarnya berawal dari praktik-praktik demokrasi yang tidak pada tempatnya.

Pemilihan pejabat politik yang berbiaya tinggi seperti itu ternyata membuahkan resiko negatif lainnya.Dulu kewibawaan para pejabat politik atau pemerintah sedemikian terasa, namun pada ahirahir ini, tatkala banyak orang berebut kursi kekuaaan, maka wibawa pejabat politik di hadapan rakyat menjadi semakin hilang karena sudah diperebutkan atau dijual belikan.Maka jabatan dan kekuasaan tidak ubahnya barang dagang dipasar.Tidak ada kewibawaan di tengah pasar atau ditempat tempat orang bertransaksi, seperti itulah tatkala kondisi jabatan dan kekuasan jika sudah dipasarkan dan diperebutkan.Kewibawaan pejabatnya juga semakin runtuh. ${ }^{15}$

Kekuasaan politik yang kita bicarakan adalah kekuatan untuk mengatur masyarakat ${ }^{16}$

\section{B. PEMILIHAN UMUM}

Pemilihan umum atau pemilu adalah suatu proses dimana para pemilih memilih orang-orang untuk mengisi jabatan-jabatan politik tertentu.definisi lain menyebutkan bahwa pemilihan umum adalah sarana pelaksanaan kedaulatan rakyat dalam negara kesatuan republik indonesia berdasarkan pancasila dan undang-undang dasar 1945. Pemilihan umum diselenggarakan secara demokratis dan transparan,

\footnotetext{
${ }^{15}$ Imam Masyarakat Tanpa Ranking (Membangun Bangsa Bersendi Agama), h 10.

${ }^{16}$ Magnis Franz.Suseno, Etika Politik (Jakarta: PT Gramedia Pustaka Utama, 2016), H.36.
} 


\section{Nadirsah Hawari, Rahma, Sinta, Asep:TARSYIH KEPEMIMPINAN .....}

jujur dan adil, dengan mengadakan pemberian dan pemungutan suara secara langsung, umum, bebas, dan rahasia ${ }^{17}$

Pemilu merupakan salah satu pilar penting dalabdm konsep Negara hukum dan konsep Negara yang menganut Negara demokrasi $^{18}$

Abdurrahman Wahid dan Amien Rais juga sepakat menjadikan demokrasi sebagai preferensi final bagi system politik atau kenegaraan $^{19}$.

1. Pemilu masa orde lama

Setelah mengalami perang berang, barulah pada tahun 1955 dilakukan pemilihan umum yang pertama kalinya dan berhasil ikut dalam kesepakatan tersebut. Partai-partai tersebut, dibawah ini:

* Partai Nasional (PNI)

* Majelis Syura Muslimin Indonesia (MASYUMI)

* Nahdlatul Ulama (NU)

* Partai Komunis Indonesia (PKI)

* Partai Syarikat Islam Indonesia (PSII)

Setelah pemilihan umum 1955 pemerintah orde lama tidak lagi melakukan pemilihan umum bahkan pihak lemabaga legislatif menyatakan Bung Karno sebagai Presiden seumur hidup. Hal ini berakhir sampai kejatuhan Bung Karno sampai peristiwa G30SPKI.

2. Pemilihan pada masa orde baru

Pemerintah orde baru mempersiapkan pemilihan umum dengan matang, yaitu dengan memasukkan ABRI dan KORPRI dalam perpolitikan Golkar. Karena strategi persiapan inilah pemilihan umum

${ }^{17}$ Ritaudin M. S., “Jurnal TAPIs Teropong Aspirasi Poltik Islam,” Jurnal TAPIs Teropong Aspirasi Poltik Islam. Bandar Lampung: Fakultas Ushuluddin Institut Agama Islam Raden Intan ., 2008.

${ }^{18}$ Solihin,Rahmat, "Jurnal Konstitusi.Vol II/No.1/Juni 2009.Referensi Islam Dalam memilih pemimpin," PKK Fakultas Syariah IAIN Antasari., h 43.

${ }^{19}$ Murod Ma'mun, Menyingkap Pemikir Politik (Gus Dur dan Amien Rais) Tentang Negara (Jakarta: PT Raja Grafindo Persada, 1999), h 17. 


\section{Nadirsah Hawari, Rahma, Sinta, Asep:TARSYIH KEPEMIMPINAN .....}

baru selenggarakan pada tahun 1971 secara lengkap. Peserta pemilihan umum tahun 1971 adalah:

* Golongan Karya (Golkar)

* Partai Naisonal Indonesia (PNI)

* Nahdlatul Ulama (NU)

* Partai Katholik

* Partai Murba

3. Pemilu masa orde reformasi

Setelah suharto jatuh dan diganti oleh Habibie, di indonesia terjadi berbagai perubahan dibidang politik diantaranya dikluarkannya:

* UU no 2 tahun 1999 tentang partai politik

* UU no 3 tahun 1999 tentang pemilihan umum

* UU no 4 tahun 1999 tentang MPR dan DPR

Sistem pemilihan umum yang dipakai tidak terlalu berbeda dengan yang dipakai pada pemilihan umum sebelumnya. Landasan hukumannya adalah UU no 2 tahun 1999.

Pada tahun 2004 diadakan 3 pemilihan umum, yaitu pertama pemilu legislatif, sekaligus untuk memilih anggota DPR, kedua pemilihan presiden dan wakil presiden putaran pertama, ketiga pemilihan presiden dan wakil presiden putaran kedua. Pemilihan umum legiislatif dilaksanakan berdasarkan UU no 12 tahun 2003 dan diikuti 24 partai, tujuh diantaranya masuk DPR yaitu: GOLKAR, PDIP, PPP, PKB, PARTAI DEMOKRAT, PKS, dan PAN ${ }^{20}$

Ketika soeharto jatuh digantikan oleh B.J.Habibie, gerakan reformasi menggulir terutama dibidang politik dan pemerintahan Habibie berusaha untuk menegakkan demokrasi dan meminta pemilihan umum dipercepat dengan mengeluarkan undang-undang H.67-71.

${ }^{20}$ Syafiie inu kencana, Etika Politik (Jakarta: Raja Grafindo Persada,), 


\section{Nadirsah Hawari, Rahma, Sinta, Asep:TARSYIH KEPEMIMPINAN .....}

no.3 tahun 1999 tentang partai politik dan pemilu. Undang-undang ini membuka kesempatan yang seluas-luasnya kepada setiap orang atau golongan untuk membentuk partai politik yang tadinya sangat terbatas dan tertutup pada masa orde baru. Menjelang pelaksanaan pemilu 1999 sudah ada 150 parti politik tercatat di departement kehakiman dan perundang-undangan, namun hanya 48 partai politik yang memenuhi persyaratan dan diperkenankan ikut menjadi peserta pemilu 1999.

Atas pertimbangan besarnya jumlah partai politik yang ada, serta banyak nya partai kecil yang tidak memenuhi syarat perolehan suara dalam pemilu 1999 maka melalui undang-undang no.12 tahun 2002, partai politik yang bisa diperkenankan ikut pemilu 5 april 2004 harus memenuhi pasal 9 yang menyatakan:

Untuk dapat mengikuti pemilu berikutnya, partai politik peserta pemilu harus:

1. Memperoleh sekurang-kurangnya 3\% (tiga persen) jumlah kursi DPR.

2. Memperoleh sekurang-kurangnya $4 \%$ (empat persen) jumlah kursi DPRD provinsi yang tersebar di $1 / 2$ (setengah) jumlah provinsi seluruh indonesia, atau

3. Memperoleh sekurang-kurangnya $4 \%$ (empat persen) jumlah kursi DPRD kabupaten atau kota yang tersebar di $1 / 2$ (setengah) jumlah kabupaten atau kota seluruh indonesia.

Jika suara partai politik itu mencapai angka 2,5\% dari jumlah suara nasional, maka dia berhak menempatkan wakilnya di parlemen, tanpa mempermasalahkan berapa jumlah kursi hasil konversi suara yang dimiliki partai politik tersebut. Sebagaimana diketahui bahwa pemilihan umum merupakan sarana untuk mewujudkan kedaulatan rakyat dalam pemerintahan negara kesatuan republik indonesia seperti diamanatkan dalam UUD 1945. Sesuai dengan tuntutan dan perkembangan dinamika masyarakat seperti yang tercermin dalam perubahan UUD 1945, pemilihan umum diselenggarakan bertujuan untuk memilih wakil rakyat dan wakil daerah, serta utuk membentuk 


\section{Nadirsah Hawari, Rahma, Sinta, Asep:TARSYIH KEPEMIMPINAN .....}

pemerintahan yang demokratis, kuat dan memperoleh dukungan rakyat $^{21}$.

\section{PARTISIPASI POLITIK}

Bentuk Partisipasi Politik dalam Kegiatan Politik

a. Golongan pejabat partai atau pemimpin partai. Karena dalam sistem politik pemerintahan yang berlaku di indonesia, belum diperbolehkan adanya calon independen non partisan. Semua kandidat harus menggunakan perahu partai, sebab proses politik harus dilaksanakan oleh partai politik.

b. Anggota partai politik dan dan kelompok kepentingan dalam proyek sosial atau administratif. Kelompok ini merupakan mesin politik yang bekerja semaksimal menkin membawa perahunya ke pantai kemenangan. Pada proses pilkada inilah tampak apakah partai tersebut diminati oleh masyarakat atau tidak, terutama program-programnya, di samping plat form dari sang kandidat, juga amat menentukan. Alternatif ditawarkan adalah gabungan dari partai-partai kecil dapat berkolaborasi memenangkan pilkada.

c. Golongan masyarakat pada umumnya seperti ikut berkampanye, mengirim tulisan tentang politik melalui media masa dan memberikan suara dalam pemilu. Kelompok ini adalah kelompok yang paling menentukan, biasanya ada kantong-kantongnya, ada simpulsimpulnya, yaitu tokoh masyarakat, tokoh adat, tokoh agama, yang merupakan figur panutan.

d. Golongan orang-orang a politis. Kelompok ini adalah mereka yang sudah muak dari pemilu ke pemilu yang mereka lihat realitas empiris masa kepemimpinan pemenang pemilu sebelumnya tidak membawa perubahan, janji tinggal janji. Mungkin juga mereka melihat dari masing-masing calon tidak menunjukkan integritas keperibadian yang dapat dijadikan panutan. Apa yang menjadi janji kampanye adalah isapan jempol belaka. Karena yang mereka pahami adalah para

\footnotetext{
${ }^{21}$ Iwan. Budi Prasetyo, (Analisis penetapan partai politik peserta pemilu) (Fakultas Hukum Universitas Sebelas Maret)., 2010), h 20.
} 


\section{Nadirsah Hawari, Rahma, Sinta, Asep:TARSYIH KEPEMIMPINAN .....}

pejabat itu tukang korupsi, pembohong dan tidak berpihak pada rakyat $^{22}$

Kita bisa melihat bagaimana kuatnya tarik-menariknya kepentingan partisipan partai politik dalam pembahasan peraturan yang sangat berkaitan betul dengan kepentingan diri mereka, maka perjuangannya akan habis-habisan meski tawar-menawar dan negosiasi juga tetap terjadi. Tak heran, jika untuk mengesahkan RUU pemilu ini pun (yang kemudian menjadi UU no.8 tahun 2012 tentang pemilu anggota DPR, DPD, dan DPRD), rapat paripurna DPR yang harus dilakukan selama 2 (dua) hari, agar bisa ketok palu ${ }^{23}$

\section{REKRUTMEN POLITIK}

\section{Wacana Rekrutmen Politik}

Rekrutmen merupakan kenyataan yang serba hadir dalam segala kehidupan politik, terutama dalam rangkaian kehidupan proses sosialisasi dan partisipasi politik dalam masyarakat. Berikut ini akan dikemukakan beberapa pengertian tentang rekrutmen politik dimaksud:

Miriam Budiarjo mendefinisikan rekrutmen politik sebagai seleksi kepemimpinan (selection of leadership), mencari dan mengajak orang yang berbakat untuk turut aktif dalam kegiatan politik. Dalam hal lembaga kegiatan politik, rekrutmen politik merupakan fungsi dari partai, yakni rangkaian peluasan lingkup partisipasi politik.

Ramlan Surbakti dalam bukunya memahami ilmu politik mengemukakan bahwa rekrutmen politik adalah seleksi dan pemilihan atau seleksi dan pengangkatan seseorang atau sekelompok orang untuk melaks anakan sejumlah peranan dalam sistem politik.

\footnotetext{
${ }^{22}$ M. S., "Jurnal TAPIs Teropong Aspirasi Poltik Islam."

${ }^{23}$ Husein Harun, Pemilu Indonesia, 2014, H.12.
} 


\section{Nadirsah Hawari, Rahma, Sinta, Asep:TARSYIH KEPEMIMPINAN .....}

Rush dan Althof, mendefinisikan rekrutmen politik sebagai proses yang individu-individunya menjamin dan mendaftarkan diri untuk menduduki suatu jabatan. Lebih lanjut, Rush dan Althof mengatakan bahwa rekrutmen atau perekrutan ini merupakan proses dua arah.

Berdasarkan pengertian-pengertian yang telah dikemukakan oleh tiga atau empat orang teoritikus politik diatas, dapat ditegaskan disini bahwa rekrutmen politik adalah proses penempatan individuindividu pada suatu jabatan politik atau jabatan administratif melalui seleksi politik yang diselenggarakan oleh lembaga politik, baik secara formal melalui pemilihan umum, yang diselenggarakan oleh Komisi Pemilihan Umum (KPU) maupun secara informal seperti penunjukan.

Menurut A.A. Said Gatara dan Moh. Dzulkiah Said, dilihat dari sifatnya, proses Rekrutmen politik itu, paling tidak ada tiga, seperti berikut ini:

Top down, Artinya Rekrutmen politik yang berasal dari atas atau orang-orang yang sedang menjabat.Sifat ini misalnya adalah penunjukan pribadi dan seleksi pengangkatan.

Bottom up, artinya proses Rekrutmen politik yang berasal dari masyarakat bawah seperti proses mendaftarkan diri dari individuindividu untuk menduduki suatu jabatan. Contoh sifat ini adalah individu-individu melamar kepada partai politik untuk maju sebagai kandidat anggota legislatif ataupun calon kepala daerah.

Dalam kerangka analisis kehidupan politik dan kekuasaan, Charles F. Andrian menyampaikan apa yang juga disampaikan Harold D. Laswell dan Abraham Kaplan (1950) mengenai sumber daya bagi aktor politik. Inti dasar kerangka analis Andrean adalah bahwa perjalanan kekuasaan yang efektif bagi seorang aktor sangat bergantung pada sumber daya politik yang tersedia. Sumber daya itu adalah: (1) Sumber daya fisik yang meliputi alat-alat kekuasaan pemaksa seperti senjata. (2) Sumber daya ekonomi yang terdiri dari kekayaan, pendapatan, kontrol atas barang dan jasa. (3) Sumber daya 


\section{Nadirsah Hawari, Rahma, Sinta, Asep:TARSYIH KEPEMIMPINAN .....}

normatif, yang melingkupi moralitas, kebenaran, kehormatan, tradisi, legitimasi, dan wewenang. (4) Personal yang meliputi kharisma pribadi (ketokohan), daya tarik, persahabatan, kasih sayang dan popularitas. (5) Sumber daya keahlian, yakni sumber daya politik berupa penguasaan informasi, pengetahuan, ketrampilan, inteligensi, serta keahlian teknis. Untuk lebih mudah memahami dapat dilihat pada tabel berikut.

\section{Rekrutmen Politik melalui Pemilu}

Rekrutmen politik melalui pemilihan umum atau pemilu sudah lazim dilaksanakan di hampir semua negara, khususnya negara-negara demokratis. Hanya saja, yang membedakan satu sama lain terletak pada mekanisme dan masa jabatan. Di indonesia, telah berlangsung sebanyak sembilan kali, yakni: Pemilu tahun 1955, pemilu tahun 1971, pemilu tahun 1977, pemilu tahun 1987, pemilu tahun 1992, pemilu tahun 1997, pemilu tahun 1999, dan pemilu tahun 2004. Kecuali pemilu tahun 2004, pemilu-pemilu sebelumnya dilaksanakan dalam kerangka merekrut para anggota dewan legislatif, baik di pusat (DPR RI) maupun di daerah (DPRD Provinsi/Kabupaten/Kota).Salah satu tugas dari para anggota dewan legislatif yang sukses terekrut (terpilih) adalah memilih kepala pemerintahan. Di pusat mereka memilih presiden dan wakil presiden, dan di daerah mereka memilih gubernur atau bupati/walikota ${ }^{24}$

\section{KESIMPULAN}

Bedasakan hasil penjelasan di atas dapat ditarik kesimpulan bahwa pencalonan dan kampanye untuk meraih jabatan politik tertentu dapat dibenarkan menurut hukum islam bagi seseorang yang dalam dirinya terdapat dua hal. Pertama, memiliki kapasitas, kapabilitas, dan akseptabilitas yang memadai untuk mengemban jabantan yang ia

${ }^{24}$ M. S., "Jurnal TAPIs Teropong Aspirasi Poltik Islam.” 


\section{Nadirsah Hawari, Rahma, Sinta, Asep:TARSYIH KEPEMIMPINAN .....}

mencalonkan dan mengkampanyekan dirinya untuk menggapainya. Kedua, motivasi utamanya tentu semata-mata untuk mencari keridhaan Allah dan demi merealisasikan kemaslahatan publik, bukan untuk menggapai kepentingan pribadi dan atau bukan sarana untuk melakukan hal-hal yang bersifat destruktif bagi kepentingan publik.

\section{DAFTAR PUSTAKA}

Assubri, M. Jurnal (Perspektif Hukum Islam Terhadap Pencalonan Diri, Dan Kampanye Untuk Jabatan Politik), Bengklelis-Riau : Jurusan Syariah STAIN, 2016.

Efriza. Political Ekplore ( Sebuah Kajian Ilmu Politik ). Bandung: Alfabeta, 2012.

Pasolong, H. Kepemimpinan Birokrasi. Bandung: Alfabeta, 2010.

Ritaudin, M. Sidi. Jurnal Tapis, Bandar Lampung: Fakultas Ushuluddin Institut Agama Islam Negri Raden Intan Lampung, 2009.

Ritaudin, M. Sidi. Jurnal Tapis Teropong Aspirasi Poltik Islam, Bandar Lampung: Fakultas Ushuluddin Institut Agama Islam Raden Intan, 2008.

Toha, M. Birokrasi Politik, Jakarta: PT. Rajagrafindo Persada, 2010.

Wirawan. Kepemimpinan, Jakarta: PT.Rajagrafindo Persada, 2013.

Suprayogo, Imam. Masyarakat Tanpa Ranking (Membangun Bangsa Bersendi Agama). Jakarta: PT Elex Media Komputindo, 2013.

Cangara, Hafied. Komunikasi Politik, Jakarta:PT Graphindo Persada, 2009.

Ritaudin, M. Sidi. Jurnal TAPIS.Vol,4/No.2/Juli-Desember.Etika Keteladanan Dalam Kepemimpinan Politik Islam.

Rosana, Elya. Jurnal Tapis.Vol 3/No2/Januari-Juni.2006.Partisipasi Politik Dan Pemimpin Masa Depan.

Budi Prasetyo, Iwan. Skripsi (Analisis Penetapan Partai Politik Peserta Pemilu), Fakultas Hukum Universitas Sebelas Maret, 2010.

Husein, Harun. Pemilu Indonesia, Jakarta: Perludem, 2014. 


\section{Nadirsah Hawari, Rahma, Sinta, Asep:TARSYIH KEPEMIMPINAN .....}

Putra, Andiko. Fenomena Perebutan Kursi "Jabatan" Legislatif Sebagai Objek Penciptaan Seni Lukis.Prodi Seni Murni-Fakultas Seni Rupa Dan Desain-Institut Seni Indonesia Padang Panjang

Duveger, Maurice Sosiologi Politik, Jakarta: PT. Raja Grafindo Persada, 2010

Cribbin, James J. Kepemimpinan Strategi Mengefektifkan Organisasi, Jakarta: PT Gramedia, 1990.

Murod, Ma'mun. Menyingkap Pemikir Politik (Gus Dur Dan Amien Rais) Tentang Negara, Jakarta: PT Raja Grafindo Persada, 1999.

Magnis, Franz Suseno. Etika Politik, Jakarta: PT Gramedia Pustaka Utama, 2016.

Solihin, Rahmat. Jurnal Konstitusi.Vol II/No.1/Juni 2009, Referensi Islam Dalam Memilih Pemimpin.Jakarta:PKK Fakultas Syariah IAIN Antasari

Supriyanto, Didik,. Menjaga Independensi Penyelenggara Pemilu (Disertai Undang-Undang No.22 Tahun 2007 Tentang Penyelenggara Pemilu).

Syafiie, Inu Kencana. Etika Politik, Jakarta: PT. Raja Grafindo Persada. 